\title{
LOGIKA DAN PENALARAN DALAM PERSPEKTIF ILMU PENGETAHUAN
}

\author{
H.A Kadir Sobur \\ Fakultas Ushuluddin IAIN STS Jambi
}

\begin{abstract}
Abstrak: logika adalah suatu cabang filsafat yang membahas tentang aturan-aturan, asas-sasa, hukum-hukum dan metode atau prosedur dalam mencapai pengetahuan secara rasional dan benar, juga merupakan suatu cara untuk mendapatkan suatu pengetahuan dengan menggunakan akal pikiran, kata dan bahasa yang dilakukan secara sistematis. Logika dapat disistematisasikan menjadi beberapa golongan hal tersebut tergantung dari perspektif mana kita melihatnya dilihat dari kualitasnya logika dapat dibedakan menjadi dua yakni logika naturalis ( logika alamiah) dan logika artifisialis (logika ilmiah). Penalaran merupakan suatu proses berpikir dalam menarik sesuatu kesimpulan yang berupa pengetahuan. Manusia pada hakikatnya merupakan makhluk yang berpikir, merasa, bersikap, dan bertindak. Sikap dan tindakannya yang bersumber pada pengetahuan yang didapatkan melalui kegiatan merasa atau berpikir. Penalaran menghasilkan pengetahuan yang dikaitkan dengan kegiatan berpikir. Penalaran merupakan suatu proses berpikir dalam menarik sesuatu kesimpulan yang berupa pengetahuan. Jadi penalaran merupakan salah satu atau proses dalam berpikir yang menggabungkan dua pemikiran atau lebih untuk menarik sebuah kesimpulan untuk mendapatkan pengetahuan baru.
\end{abstract}

Kata Kunci: Logika, Penalaran, Ilmu Pengetahuan

\section{Pendahuluan}

Filsafat dan ilmu pengetahuan adalah dua produk dan nalar peradaban manusia yang saling berkait erat. Manusia menjalankan amanah sebagai khalifah dan abdi Allah, selain oleh agama ia juga dituntun oleh filsafat dan ilmu pengetahuan. ${ }^{1}$ Jadi manusia adalah

\footnotetext{
${ }^{1}$ Iu Rusliana. Filsafat Ilmu. Bandung: Refika Aditama: 2015. 1.
} 
sebagai pemegang amanah terhadap pemeliharaan dunia oleh karenanya manusia memerlukan penegathuan dan pemikiran dalam mengemban tugas tersebut.

Dalam sejarah Islam pada awalnya berkembang pemikiranpemikiran rasional, akan tetapi kemudian berkembang pemikiran tradisional. Pemikiran rasional berkembang pada zaman Klasik Islam (650-1250 sedangkan pemikiran tradisional berkembang pada Zaman Pertengahan Islam ( 1250-1800 M). Dalam hal ini pemikiran rasional dipengaruhi oleh persepsi bagaimana tingginya kedudukan akal seperti terdapat dalam Al-Qur'an dan Hadits. ${ }^{2}$ Pertemuan Islam dan peradaban Yunani melahirkan pemikiran rasional dikalangan ulama Islam zaman Klasik. Namun terdapat perbedaan antara pemikiran rasional Yunani dan pemikiran rasional Islam zaman Islam Klasik. ${ }^{3}$

Manusia adalah makhluk hidup yang sempurna, itulah ungkapan yang sering kita dengar dalam kehidupan sehari-hari kita. Manusia sebagai ciptaan Tuhan yang paling sempurna memang memiliki banyak kelebihan dibanding makhluk lainnya. Sebagai ciptaan-Nya yang sempurna manusia dibekali akal dan pikiran untuk bisa dikembangkan berbeda dengan hewan yang juga memiliki akal dan pengetahuan tapi hanya sebatas untuk mempertahankan dirinya.

Menurut Suhartono Manusia mempunyai kemampuan menalar, artinya berpikir secara logis dan analitis. Kelebihan manusia dalam kemampuannya menalar dan karena mempunyai bahasa untuk mengkomunikasikan hasil pemikirannya yang abstrak, maka manusia bukan saja mempunyai pengetahuan, melainkan juga mampu mengembangkannya. Karena kelebihannya itu maka Aristoteles memberikan identitas kepada manusia sebagai "animal rationale". 4

2 Lihat. Departemen Agama RI. Al-Qur'an dan Terjemahannya. Surabaya: Surya Cipta Aksara. 1995. ( Surat Ath-Thalaq:10, Al Jin: 4, Qaaf: 37, Az-zumar: 18,21, Al-A'raf: 66,67).

${ }^{3}$ Harun Nasution. Islam Rasional. Bandung: Mizan. 1996. 7.

${ }^{4}$ Suparlan Suhartono, Sejarah Pemikiran Filsafat Modern .Yogyakarta: Ar Ruzz Media, 2005, 1. 
Seiring dengan perkembangan zaman, manusia sering mengabaikan atau bahkan melupakan logika dalam berfikir dan membuat aturan. Kebanyakan orang-orang tersebut menganggap remeh tentang logika dan berfikir seenaknya saja, mereka mengiginkan suatu hal yang mudah dan praktis. Sehingga yang terjadi adalah kejanggalan-kejanggalan dalam komunitas mesyarakat banyak.

Perlu disadari bahwa sesuatu yang logis biasanya akan mudah dipahami oleh nalar kita tetapi sesuatu yang tidak logis kadang bertentangan dengan pikiran dan hati kita. Dalam banyak hal kita sering mengalami berbagai kejadian yang kita pikir tidak logis misalnya ada yang jelas-jelas melakukan korupsi dengan uang milliaran rupiah bahkan triliunan rupiah tapi di mata hukum disamakan dengan seorang pencuri seekor ayam. Ada juga yang jelas terbukti bersalah tetapi tidak tersentuh oleh hukum.

Atas dasar realitas tersebut diperlukan suatu logika dalam kehidupan manusia agar kita mengetahui kapan saatnya berpikir logis, kapan saatnya berpikir tidak logis, setiap tempat dan waktu ada logikanya, setiap logika ada waktu dan tempatnya. Memahami hakikat keduanya haruslah dengan baik dan benar justru kita menempatkan diri dalam segala keadaan serta proporsional di tengah manusia yang bervariasi tingkat logika dan pemikirannya. Peristiwa yang terjadi pasti menimbulkan penalaran, apakah sesuai dengan kehendak berpikir atau tidak sesuai sama sekali. ${ }^{5}$ Maka dengan demikian penggunaan logika dalam konteks kehidupan keseharian memang sangat dibutuhkan hal ini menunjukkan sejauh mana kapasitas individu tersebut dalam memanfaatkan dan memaksimalkan potensi diri.

\section{Hakikat Logika}

Menurut K. Prent C.M.T Adisubrata dalam Mundiri mengatakan bahwa logika adalah berasal daribahasa latin 'logos' yang berarti perkataan atau sabda. ${ }^{6}$ Kemudian menurutnya juga istilah lain sering juga disebut mantiq, berasal dari kata arab yang

${ }^{5}$ Mukhtar Latif, Orientasi ke Arah Filsafat Ilmu . Jakarta: Kencana Prenadamedia Group, 2014, 255-256.

${ }^{6}$ Mundiri, Logika, Jakarta: PT.Raja Grafindo Persada, 2008. 1. 
diambil dari kata nataqa yang berarti berkata atau berucap. ${ }^{7}$ Kemudian George F. Kneller dalam buku Logic of Lenguage Education, dalam Susanto mendefinisikan logika disebut sebagai penyelidikan tentang dasar-dasar dan metode berfikir benar (correct reason). ${ }^{8}$ Sedangkan menrut Irving M.Copi dalam Mundiri memaknai kata logika adalah ilmu yang mempelajari metode dan hukum-hukum yang digunakan untuk membedakan penalaran yang betul dan penalaran yang salah. ${ }^{9}$ Selanjutnya hampir sejalan dengan yang dikemukakan oleh Irving, W. Poespoprodjo dalam Susanto memberikan definisi logika yakni "Logika menunjukkan, meletakkan, menguraikan dan membuktikan hukum-hukum dan aturan-aturan yang akan menjaga kita agar tidak terjerumus dalam kekeliruan (kesetatan). ${ }^{10}$

Jadi berdasarkan pada pengertian-pengertian yang telah dikemukakan oleh para ahli diatas tentang logika dapat di fahami bahwa pemahaman tentang logika adalah suatu cabang filsafat yang membahas tentang aturan-aturan, asas-sasa, hukum-hukum dan metode atau prosedur dalam mencapai pengetahuan secara rasional dan benar.

Kita sudah begitu sering berpikir, rasa-rasanya berpikir begitu mudah. Semenjak kecil kita sudah biasa melakukannya. Setiap hari kita berdialog dengan diri kita sendiri, berdialog dengan orang lain, berbicara, menulis, membaca suatu uraian, mengkaji suatu tulisan, mendengarkan penjelasan-penjelasan dan mencoba menarik kesimpulan-kesimpulan dari apa yang kita lihat dan kita dengar. Terus-menerus sering kali hampir tanpa rasa disadari.

Namun, apabila diselidiki lebih lanjut, dan terutama bila harus dipraktekkan sungguh-sungguh, ternyata bahwa berpikir dengan teliti dan tepat merupakan kegiatan yang cukup sukar juga. Manakala kita meneliti dengan seksama dan sistematis berbagai penalaran, segera akan dapat diketahui bahwa banyak penalaran tidak menyambung. Di dalam kegiatan berpikir, benar-benar

${ }^{7}$ Ibid. hal 2

8 Susanto, Filsafat Ilmu Suatu Kajian dalam Dimensi Ontologis, Epistemologis dan Aksiologis, Jakarta: Bumi Aksara, 2011. 144

${ }^{9}$ Mundiri, 2.

${ }^{10}$ Susanto, 144. 
dituntut kesanggupan pengamatan yang kuat dan cermat; dituntut kesanggupan melihat hubungan-hubungan, kejanggalankejanggalan, kesalahan-kesalahan yang terselubung dan lain sebagainya.

Orang biasanya menganggap benar apa yang disukainya, apa yang dimauinya. Perasaan dan prasangka dapat bahkan sering mengelabui atau mengaburkan pandangan mata kita sehingga terjadi kesimpulan-kesimpulan yang ngawur. Selain itu kebiasaankebiasaan dan pendapat umum mempengaruhi jalan pikiran kita. Dalam praktek sering kali sulit untuk mengajukan alasan yang tepat, atau menunjukkan mengapa suatu pendapat tidak dapat kita terima.

Keinsafan akan adanya kesulitan-kesulitan itu mendorong orang untuk memikirkan caranya ia berpikir, serta meneliti asasasas hukum yang harus mengatur pemikiran manusia agar dapat mencapai kebenaran. Dengan demikian timbullah suatu ilmu yang disebut logika, yang dipelopori oleh Aristoteles (348 - 322 SM) dengan karyanya yang terkenal To Organon. Logika melatih kita untuk dapat membedakan pemikiran yang tepat, lurus dan benar dari yang kacau serta salah yakni pikiran yang rompang-ramping.

Menurut Andre Ata, dkk dalam Mukhtar konsep logika atau logis sudah sering kita dengar dan kita gunakan. Dalam bahasa sehari-hari perkataan logika atau logis menunjukkan cara berpikir atau cara hidup atau sikap hidup tertentu yaitu yang masuk akal, yang wajar, yang beralasan atau berargumen, ayang ada rasionya atau hubungan-hubungan rasionalnya yang dapat dimengerti walaupun belum tentu disetujui tentang benar atau salahnya. Dapat dikatakan bahwa bahwa logika adalah kajian dalam proses penalaran yang bertolak dari penerapan prinsip berpikir dalam suatu penalaran yang tepat yang digunakan dalam membedakan yang baik dan yang benar dari penalaran yang buruk dan salah. ${ }^{11}$

Semua orang mengakui memiliki pengetahuan. Namun dari mana pengetahuan itu diperoleh atau lewat apa pengetahuan itu di dapat. Dari sana timbul pertanyaan bagaimana kita memperoleh pengetahuan atau dari mana sumber pengetahuan didapat. Terdapat berbagai upaya yang dapat dilakukan oleh manusia untuk

\footnotetext{
${ }^{11}$ Loc. Cit. Mukhtar Latif.
} 
memperoleh pengetahuan, misalnya ia dapat melakukannya dengan jalan bertanya kepada orang lain (yang memiliki otoritas) yang dianggapnya lebih tahu, atau ia dapat melakukannya melalui indra, akal sehat, intuisi atau dengan coba-coba.

Berfikir merupakan suatu kegiatan untuk menemukan pengetahuan yang benar. Apa yang disebut benar bagi tiap orang tidak selalu sama. Oleh sebab itu, kegiatan proses berfikir untuk menghasilkan pengetahuan yang benar pun juga berbeda-beda. Dapat dikatakan bahwa tiap jalan pikiran mempunyai apa yang disebut sebagai kriteria kebenaran yang merupakan landasan bagi proses penemuan kebenaran tersebut. Penalaran merupakan suatu proses penemuan kebenaran dimana tiap-tiap jenis penalaran mempunyai kriteria kebenarannya masing-masing.

Penalaran merupakan suatu proses berpikir dalam menarik sesuatu kesimpulan yang berupa pengetahuan. Manusia pada hakikatnya merupakan makhluk yang berpikir, merasa, bersikap, dan bertindak. Sikap dan tindakannya yang bersumber pada pengetahuan yang didapatkan melalui kegiatan merasa atau berpikir. Penalaran menghasilkan pengetahuan yang dikaitkan dengan kegiatan berpikir dan bukan dengan perasaan, meskipun seperti dikatakan Pascal, hatipun mempunyai logika tersendiri. Meskipun demikian patut kita sadari bahwa tidak semua kegiatan berpikir menyandarkan diri pada penalaran. Jadi, penalaran merupakan kegiatan berpikir yang mempunyai karakteristik tertentu dalam menemukan kebenaran.

Agar pengetahuan yang dihasilkan dari penalaran itu mempunyai dasar kebenaran maka proses berpikir itu harus dilakukan dengan suatu cara tertentu. Penarikan kesimpulan dianggap benar jika penarikan kseimpulan dilakukan menurut cara tertentu tersebut. Cara penarikan kesimpulan ini disebut dengan logika.

\section{Sejarah Perkembangan Logika}

Berdasarkan sumber yang ada awal munculnya logika tidak dapat ditetapkan kepastiannya. Namun menurut Betrand Russel dalam bukunya "History of Western Philoshopy" menjelaskan bahwa kata logika untuk pertama kali dipergunakan oleh Zeno dari Citium. Russel juga menjelaskan bahwa Socrates, Plato dan 
Aristoteles merupakan perintius lahirnya ilmu logika. Kemudian berbeda dengan K. Bertens menyatakan bahwa logika pertama muncul pada masa Cicero (abad ke-1 SM) yang dimaknai sebagai seni berdebat, kemudian setelah itu pada pasa Aristoteles baru dikenal dengan kata 'analitika' yang bertugas menyelidiki argumen-argumen yang bertolak dari keputusan-keputusan yang benar. $^{12}$

Aristoteles (384-322 SM), memaknai logika sebagai sebuah ilmu tentang hukum-hukum berpikir guna memelihara jalan pikiran dari setiap kekeliruan. Logika sebagai ilmu baru pada waktu itu, disebut dengan nama "analitika" dan "dialektika". Kumpulan karya tulis Aristoteles mengenai logika diberi nama Organon.

Theoprastus (371-287 SM), memberi sumbangan terbesar dalam logika ialah penafsirannya tentang pengertian yang mungkin dan juga tentang sebuah sifat asasi dari setiap kesimpulan. Kemudian, Porphyrius (233-306 M), seorang ahli pikir di Iskandariah menambahkan satu bagian baru dalam pelajaran logika. Bagian baru ini disebut Eisagoge, yakni sebagai pengantar Categorie. Dalam bagian baru ini dibahas lingkungan-lingkungan zat dan lingkungan-lingkungan sifat di dalam alam, yang biasa disebut dengan klasifikasi.

Karya Aristoteles tentang logika dalam buku Organon dikenal di dunia Barat selengkapnya ialah sesudah berlangsung penyalinanpenyalinan yang sangat luas dari sekian banyak ahli pikir Islam ke dalam bahasa Latin. Penyalinan-penyalinan yang luas itu membukakan masa dunia Barat kembali akan alam pikiran Grik Tua.

Petrus Hispanus (1277 M) menyusun pelajaran logika berbentuk sajak, seperti All-Akhdari dalam dunia Islam, dan bukunya itu menjadi buku dasar bagi pelajaran logika sampai abad ke-17. Petrus Hispanus inilah yang mula-mula mempergunakan berbagai nama untuk sistem penyimpulan yang sah dalam perkaitan bentuk silogisme kategorik dalam sebuah sajak. Dan kumpulan sajak Petrus Hispanus mengenai logika ini bernama Summulae.

Francis Bacon (1561-1626 M) melancarkan serangan sengketa terhadap logika dan menganjurkan penggunaan sistem induksi

\footnotetext{
${ }^{12}$ Susanto, 145.
} 
secara lebih luas. Serangan Bacon terhadap logika ini memperoleh sambutan hangat dari berbagai kalangan di Barat, kemudian perhatian lebih ditujukan kepada penggunaan sistem induksi.

Pembaruan logika di Barat berikutnya disusul oleh lain-lain penulis di antaranya adalah Gottfried Wilhem von Leibniz. Ia menganjurkan penggantian pernyataan-pernyataan dengan simbolsimbol agar lebih umum sifatnya dan lebih mudah melakukan analisis. Demikian juga Leonard Euler, seorang ahli matematika dan logika Swiss melakukan pembahasan tentang term-term dengan menggunakan lingkaran-lingkaran untuk melukiskan hubungan antarterm yang terkenal dengan sebutan circle-Euler.

John Stuart Mill pada tahun 1843 mempertemukan sistem induksi dengan sistem deduksi. Setiap pangkal-pikir besar di dalam deduksi memerlukan induksi dan sebaliknya induksi memerlukan deduksi bagi penyusunan pikiran mengenai hasil-hasil eksperimen dan penyelidikan. Jadi, kedua-duanya bukan merupakan bagianbagian yang saling terpisah, tetapi sebetulnya saling membantu. Mill sendiri merumuskan metode-metode bagi sistem induksi, terkenal dengan sebutan Four Methods.

Logika Formal sesudah masa Mill lahirlah sekian banyak buku-buku baru dan ulasan-ulasan baru tentang logika. Dan sejak pertengahan abad ke-19 mulai lahir satu cabang baru yang disebut dengan Logika-Simbolik. Pelopor logika simbolik pada dasarnya sudah dimulai oleh Leibniz.

Logika simbolik pertama dikembangkan oleh George Boole dan Augustus de Morgan. Boole secara sistematik dengan memakai simbol-simbol yang cukup luas dan metode analisis menurut matematika, dan Augustus De Morgan (1806-1871) merupakan seorang ahli matematika Inggris memberikan sumbangan besar kepada logika simbolik dengan pemikirannya tentang relasi dan negasi.

Tokoh logika simbolik yang lain ialah John Venn (18341923), ia berusaha menyempurnakan analisis logik dari Boole dengan merancang diagram lingkaran-lingkaran yang kini terkenal sebagai diagram Venn (Venn's diagram) untuk menggambarkan hubungan-hubungan dan memeriksa sahnya penyimpulan dari silogisme. Untuk melukiskan hubungan merangkum atau 
menyisihkan di antara subjek dan predikat yang masing-masing dianggap sebagai himpunan.

Perkembangan logika simbolik mencapai puncaknya pada awal abad ke-20 dengan terbitnya 3 jilid karya tulis dua filsuf besar dari Inggris Alfred North Whitehead dan Bertrand Arthur William Russell berjudul Principia Mathematica (1910-1913) dengan jumlah 1992 halaman. Karya tulis Russell-Whitehead Principia Mathematica memberikan dorongan yang besar bagi pertumbuhan logika simbolik.

Dalam dunia islam logika berkembang yaitu pada zaman kejayaan Islam. Islam ketika itu telah berkembang sampai ke Spanyol di barat dan ke timur mencapi perbatasan Cina. Zaman itu adalah zaman perkembangan ilmu pengetahuan dan dilakukan penterjemahan buku-buku Yunani kuno, Persia dan Sansekerta ke bahasa Arab di zaman Khalifah Al-Ma'un dari daulat Abbasyiah di Babdad dan Khalifah

Di Indonesia pada mulanya logika tidak pernah menjadi mata pelajaran pada perguruan-perguruan umum. Pelajaran logika cuma dijumpai pada pesantren-pesantren Islam dan perguruan-perguruan Islam dengan mempergunakan buku-buku berbahasa Arab. Pada masa sekarang ini logika di Indonesia sudah mulai berkembang sesuai perkembangan logika tersebut pada umumnya yang mendasarkan pada perkembangan ilmu pengrtahuan.

\section{Logika dan Penalaran}

Pembagian Logika

Logika berasal dari kata Yunani kuno (logos) yang berarti hasil pertimbangan akal pikiran yang diutarakan lewat kata dan dinyatakan dalam bahasa. Menurut Cecep Sumarna dalam Susanto logika adalah cara penarikan kesimpulan atau pengkajian untuk berpikir secara shahih. ${ }^{13}$

Jan Hendrik Rapar menjelaskan istilah logika diambil dari bahasa Yunani logikos, yang berarti mengenai sesuatu yang diutarakan, suatu pertimbangan akal (pikiran), mengenai kata, mengenai percakapan atau berkenaan dengan bahasa. Menurut Poedjawijatna logika adalah kajian filsafat yang mengkaji manusia

13 Susanto, Filsafat Ilmu Suatu Kajian dalam Dimensi Ontologis, Epistemologis dan Aksiologis. Jakarta: Bumi Aksara, 2013, 144-145. 
yang biasanya dikenal dengan filsafat budi, dimana pengertian budi disini adalah akal sebagai alat penyelidikan dalam mengambil suatu tindakan atau keputusan. ${ }^{14}$

Menurut Poespoprojo logika adalah ilmu kecakapan menalar atau berfikir dengan tepat (The Science and art of correct thingking). Pengertian diatas mengindikasikan bahwa berfikir atau menalar adalah kegiatan akal budi manusia untuk mengolah pengetahuan yang kita terima melalui panca indra dan ditujukan untuk mencapai suatu kebenaran. Berfikir menunjukkan suatu bentuk kegiatan akal yang khas dan terarah. Dalam katagori ini hasil lamunan dan hayalan tidak termasuk kegiatan berfikir. Suatu pemikiran dikatakan tepat dan jitu bila dilakukan dengan penganalisaan, pembuktian dengan alasan-alasan tertentu dan adanya kaitan antara yang satu dengan lainnya. Pemikiran yang demikian disebut dengan logis.

Jalan pemikiran yang mengesampingkan hal-hal tersebut diatas dikatagorikan pemikiran yang tidak logis. Logika merupakan ilmu yang fundamental yang secara sistematis menyelidiki, merumuskan dan menerangkan asas-asas yang harus ditaati agar orang dapat berfikir dengan tepat, lurus dan teratur. Maksud dan tujuan logika adalah kecakapan menerapkan aturan-aturan pemikiran yang tepat terhadap persoalan-persoalan yang kongkrit yang kita hadapi, serta pembiasaan sikap ilmiah, kritis dan obyektif.

Menurut Amsal Bakhtiar logika adalah sarana untuk berpikir dengan sistematis, tertaur, terarah, valid dan dapat dipertanggungjawabkan. Karena itu berpikir logis adalah berpikir sesuai dengan aturan-aturan berpikir, seperti setengah tidak boleh lebih dari satu. ${ }^{15}$ Dari pendapat di atas maka dapat disimpulkan logika merupakan suatu cara untuk mendapatkan suatu pengetahuan dengan menggunakan akal pikiran, kata dan bahasa yang dilakukan secara sistematis.

Logika dapat disistematisasikan menjadi beberapa golongan hal tersebut tergantung dari perspektif mana kita melihatnya,

${ }^{14}$ Ibid., 144.

${ }^{15}$ Amsal Bakhtiar, Filsafat Ilmu. Jakarta: Raja Grafindo Persada, 2004, 212. 
dilihat dari kualitasnya logika dapat dibedakan menjadi dua yakni logika naturalis ( logika alamiah) dan logika artifisialis (logika ilmiah) yakni : ${ }^{16}$

Logika Naturalis (alamiah)

Logika naturalis adalah kecakapan berlogika berdasarkan akal bawaan manusia. Akal manusia yang normal dapat bekerja secara spontan sesuai hukum-hukum logika dasar. Kemampuan logika naturalis antara manusia yang satu dengan yang lainnya adalah berbeda-beda. Tergantung dari tingkat intelegensi dan pengetahuannya. Maka kinerja akal budi manusia yang berpikir secara tepat dan lurus secara natural tanpa dipengaruhi oleh keinginan-keinginan dan kecenderungan-kecenderungan yang subjektif dari pemikir atau manusia. Kemampuan logika alamiah manusia ada sejak lahir.

Logika Artifisialis (Logika ilmiah).

Logika ilmiah memperhalus, mempertajam pikiran serta akal budi. Logika ilmiah menjadi ilmu khusus yang merumuskan asasasas yang harus ditepati dalam setiap pemikiran. Berkat pertolongan logika ilmiah inilah akal budi dapat bekerja dengan lebih tepat, lebih teliti, lebih mudah dan lebih aman. Logika ilmiah dimaksudkan untuk menghindarkan kesesatan atau paling tidak, mengurangi kesesatan. Di Barat yang pertama sekali merumuskan kaidah-kaidah tentang logika artificialis adalah Aristoteles yang tertera di dalam bukunya organon yang berarti instrumen (alat) yakni alat untuk berfikir benar.

Namun demikian, jika dipandang dari segi objeknya maka logika artificialis dapat dibagi menjadi dua yakni logika formal dan logika material. Logika formal sering juga disebut logika minor sedangkan logika material disebut logika mayor. Logika formal adalah mempelajari asas-asas aturan-aturan atau hukum-hukum berfikir yang harus di taati, agar orang dapat berfikir dengan benar dan menca[pai kebenaran. Logika material mempelajari sumbersumber dan asalnya pengetahuan, alat-alat pengetahuan, proses terjadinya pengetahuan, dan akhirnya merumuskan metode pengetahuan tersebut. ${ }^{17}$

\footnotetext{
${ }^{16}$ Mundiri. 15

${ }^{17}$ Hasbullah Bakri, Sistematik Filsafat, Jakarta: Widjaya. 1986. 20-21.
} 
Secara terperinci, logika digunakan untuk membantu setiap orang yang mempelajari logika untuk berpikir secara rasional, kritis, lurus, tetap, tertib, metodis dan koheren. Meningkatkan kemampuan berpikir secara abstrak (berpikir tingkat tinggi), cermat dan objektif. Menambah kecerdasan dan meningkatkan kemampuan berpikir secara tajam dan mandiri. Memaksa dan mendorong orang untuk berpikir sendiri dengan menggunakan asas-asas sistematis. Meningkatkan cinta akan kebenaran dan menghindari kesalahan-kesalahan berpikir, kekeliruan serta kesesatan. Mampu melakukan analisis terhadap suatu kejadian.

Penalaran

Manusia diberikan oleh Allah Swt memiliki kelebihan dari makhluk lainnya sehingga manusia deberikan kemampuan untuk berfikir, merasa, mendengar, melihat, bersekap dan berbuat dengan benar. Sikap dan tindakan diperoleh atau bersumber pada penegetahuan yang diperoleh dengan melalui kegiatan dan proses berfikir, merasa dan melihat serta mendengar. Penalaran hasil pengetahuan yang dikaitkan dengan proses berfikir dan tindakan dikaitkan dengan perasaan dalam hal ini seorang ahli fisika yaitu Pascal menyatakan bahwa ternyata hati juga mempunyai logikanya sendiri. Dalam hal ini perlu diketahui juga logikanya kita sadari bawa tidak semua kegiatan berfikir itu didasarkan pada penalaran. Artinya penalaran adalah kegiatan berfikir yang memiliki karateristik tertentu dalam menemukan suatu kebenaran. Dengan demikian manusia dalam melakukan kegiatan berfikir tidak selalu didasarkan pada penalaran, namun ada juga kegiatan berfikir yang didadasrkan pada perasaan dan intuisi. ${ }^{18}$

Penalaran merupakan suatu proses berpikir dalam menarik sesuatu kesimpulan yang berupa pengetahuan. Menurut Adib nalar adalah salah satu corak berpikir untuk menggabungkan dua pemikiran atau lebih dengan maksud untuk mendapatkan pengetahuan baru dengan memperhatikan asas-asas pemikiran, yaitu principium identitas, principium contradictionis, principiumtertii exclusi dan principium kompromi. Jadi penalaran merupakan salah satu atau proses dalam berpikir yang

${ }^{18}$ Fuad Ihsan, Filsafat Ilmu, Jakarta: Rineka Cipta.2010. 118 
menggabungkan dua pemikiran atau lebih untuk menarik sebuah kesimpulan untuk mendapatkan pengetahuan baru.

Logika merupakan ketentuan formal untuk memeperoleh pengetahuan yang benar. ${ }^{19}$ Prinsip penalaran menurut Aristoteles ada 3 yaitu prinsip identitas yaitu suatu hal adalah sama dengan halnya sendiri, prinsip kontradiksi yaitu sesuatu tidak dapat sekaligus merupakan hal itu dan bukan hal itu pada waktu yang bersamaan dan prinsip eksklusi tertii yaitu prinsip penyisihan jalan tengah atau prinsip tidak adanya kemungkinan ketiga. ${ }^{20}$ Ada dua macam penalaran, yaitu: ${ }^{21}$

Penalaran Langsung

Penalaran langsung merupakan penalaran yang premisnya hanya sebuah proposisi dan langsung disusul dengan proposisi lain sebagai kesimpulannya. Penalaran langsung ditarik hanya dari satu premis saja. Penarikkan konklusi secara langsung dapat memberikan keterangan yang lengkap tentang proposisi yang diberikan, yaitu dengan menyatakan secara eksplisit apa-apa yang telah dinyatakan secara implisit didalam premis. Contoh : semua bintang sepak bola memakai sampo Rejois $(\mathrm{S}=\mathrm{P})$ Jadi, sebagian pemakai sampo Rejois adalah bintang film Istilah penalaran langsung berasal dari Aristoteles untuk menunjukkan penalaran, yang premisnya hanya terdiri dari sebuah proposisi saja. Konklusinya ditarik langsung dari proposisi yang satu itu dengan membandingkan subjek dan predikatnya.

Penalaran tidak langsung

Penalaran tidak langsung, penarikan konklusinya atas lebih dari satu proposisi. Konklusinya ditarik dari dua premis. Contoh: Semua siswa adalah anak rajin. Budi adalah mahasiswa. Budi adalah anak rajin.

19 Susanto, Filsafat Ilmu Suatu Kajian dalam Dimensi Ontologis, Epistemologis dan Aksiologis. Jakarta: Bumi Aksara, 2013, 143.

20 Surajiyo, Filsafat Ilmu dan Perkembangannya di Indonesia. Jakarta: Bumi Aksara, 2013, 111-112.

21 Jujun S. Suriassumantri. Filsafat Ilmu: Sebuah Pengantar Populer. Jakarta : Pustaka Sinar Harapan. 2009, 156. 
Penalaran merupakan konsep yang paling umum menunjuk pada salah satu proses pemikiran untuk sampai pada suatu kesimpulan sebagai pernyataan baru dari beberapa pernyataan lain yang telah diketahui. Pernyataan itu terdiri dari pengertianpengertian sebagai unsurnya yang antara pengertian satu dengan yang lainnya ada batas-batas tertentu untuk menghindari kekaburan arti.

Penalaran merupakan suatu pemikiran jenis yang khusus, yang didalamnya penyimpulan terjadi, atau didalamnya kesimpulan ditarik dari premis-premis yang ada atau penalaran merupakan proses berpikir yang bertolak dari pengamatan indera (pengamatan empiris atau sesuai fakta di lapangan) yang menghasilkan sejumlah konsep dan pengertian. Berdasarkan pengamatan yang sejenis juga akan terbentuk proposisi-proposisi yang sejenis, berdasarkan sejumlah proposisi yang diketahui atau dianggap benar, orang menyimpulkan sebuah proposisi baru yang sebelumnya tidak diketahui. Proses inilah yang disebut menalar.

Dalam penalaran, proposisi yang dijadikan dasar penyimpulan disebut dengan premis (antesedens) dan hasil kesimpulannya disebut dengan konklusi (consequence). Hubungan antara premis dan konklusi disebut konsekuensi. Penalaran adalah suatu proses berpikir dengan menghubungkan bukti, fakta, petunjuk atau eviden, atau pun sesuatu yang dianggap bahan bukti, menuju suatu kesimpulan.

Dalam kamus umum Bahasa Indonesia, penalaran berasal dari kata nalar yang berarti pertimbangan baik buruk, budi pekerti dan akal budi. Dari pengertian tersebut terdapat kata akal yang merupakan sarana untuk berfikir. Kemampuan menalar hanya di miliki oleh manusia. Dengan kemampuan menalar manusia dapat mengembangkan pengetahuan lainyang kian hari kian berkembang.

Dari pengetahuan hasil penalaran, manusia dapat menentukan nilai moral, etika dan estetika. Tujuan manusia mengembangkan pengetahuan adalah untuk mengatasi dan memenuhi tantangan hidup. Pengetahuan yang diperoleh dari hasil penalaran akan terus berkembang. Faktor yang menyebabkan pengetahuan berkembang dengan pesat adalah bahasa merupakan sarana komunikasi yang sangat efektif dan penting dalam kehidupan manusia yang 
berfungsi untuk menyampaikan informasidan jalan fikiran yang melatar belakangi informasi tersebut kepada orang lain, baik secara lisan maupun tulisan.

Kerangka berfikir yang dimaksud adalah di mulai dengan mengamati fakta dan data, menganalisa hubungan sebab akibat sampai kepada penarikan sebuah kesimpulan. Penalaran merupakan kegiatan berfikir yang mempunyai karakteristik tertentu dalam menemukan kebenaran. Karekteristik tersebut ditandai dengan pola berfikir yang runtut dengan menggunakan kaidah-kaidah yang baku.

Sedangkan Logika dapat di simpulkan tentang penalaran dan ilmu berfikir. Jadi ilmu logika adalah satu ilmu pengetahuan yang dibicarakan tentang aturan-atura berfikir dan bekomunikasi,agar dengan aturan-aturan tersebut dapat diambil kesimpulan yang benar dan tepat.

Dalam penalaran logika dibagi atas dua unsur, deduktif dan induktif. Penalaran deduktif kadang disebut logika, deduktif adalah penalaran yang membangun atau mengevaluasi argumen deduktif. Argumen dinyatakan deduktif jika kebenaran dari kesimpulan ditarik atau merupakan konsekuensi logis dari premis-premisnya. Argumen deduktif dinyatakan valid atau tidak valid, bukan benar atau salah.

Sebuah argumen deduktif dinyatakan valid jika dan hanya jika kesimpulannya merupakan konsekuensi logis dari premispremisnya. Logika sebagai teori penyimpulan, berlandaskan pada suatu konsep yang dinyatakan dalam bentuk kata atau istilah, dan dapat diungkapkan dalam bentuk himpunan sehingga setiap konsep mempunyai himpunan, mempunyai keluasan. Dengan dasar himpunan karena semua unsur penalaran dalam logika pembuktiannya menggunakan diagram himpunan, dan ini merupakan pembuktian secara formal jika diungkapkan dengan diagram himpunan sah dan tepat karena sah dan tepat pula penalaran tersebut.

Berdasarkan proses penalarannya dan juga sifat kesimpulan yang dihasilkannya, logika dibedakan antara logika deduktif dan logika induktif. Logika deduktif adalah sistem penalaran yang menelaah prinsip-prinsip penyimpulan yang sah berdasarkan 
bentuknya serta kesimpulan yang dihasilkan sebagai kemestian diturunkan dari pangkal pikirnya. Dalam logika ini yang terutama ditelaah adalah bentuk dari kerjanya akal jika telah runtut dan sesuai dengan pertimbangan akal yang dapat dibuktikan tidak ada kesimpulan lain karena proses penyimpulannya adalah tepat dan sah.

Logika deduktif karena berbicara tentang hubungan bentukbentuk pernyataan saja yang utama terlepas isi apa yang diuraikan karena logika deduktif disebut pula logika formal. Logika induktif adalah sistem penalaran yang menelaah prinsip-prinsip penyimpulan yang sah dari sejumlah hal khusus sampai pada suatu kesimpulan umum yang bersifat boleh jadi. Logika ini sering disebut juga logika material, yaitu berusaha menemukan prinsipprinsip penalaran yang bergantung kesesuaiannya dengan kenyataan, oleh karena itu kesimpulannya hanyalah keboleh-jadian, dalam arti selama kesimpulannya itu tidak ada bukti yang menyangkalnya maka kesimpulan itu benar, dan tidak dapat dikatakan pasti.

Jika dikonsepkan bentuk logis adalah inti dari logika. Konsep itu menyatakan bahwa kesahihan (validitas) sebuah argumen ditentukan oleh bentuk logisnya, bukan oleh isinya. Dalam hal ini logika menjadi alat untuk menganalisis argumen, yakni hubungan antara kesimpulan dan bukti atau bukti-bukti yang diberikan (premis). Logika silogistik tradisional Aristoteles dan logika simbolik modern adalah contoh-contoh dari logika formal.

Dasar penalaran dalam logika ada dua, yakni deduktif dan induktif. Penalaran deduktif kadang disebut logika deduktif adalah penalaran yang membangun atau mengevaluasi argumen deduktif. Argumen dinyatakan deduktif jika kebenaran dari kesimpulan ditarik atau merupakan konsekuensi logis dari premis-premisnya. Argumen deduktif dinyatakan valid atau tidak valid, bukan benar atau salah.

Bentuk Berpikir dan Bangunan Logika

Menurut Darsono Prawironegoro dalam Mukhtar bahwa logika adalah suatu metode yang diciptakan untuk meneliti ketepatan penalaran. Bentuk-bentuk pemikiran yaitu pengertain atau konsep, proposisi atau pertanyaan dan penalaran. Tidak ada 
proposisi tanpa pengertian dan tidak ada penalaran dalm proposisi. $^{22}$ Berfikir merupakan konsep kunci dalam setiap diskursus mengenai kedudukan manusia di muka bumi, ini berarti bahwa tanpa berfikir, kemanusiaan manusia pun tidak punya makna bahkan mungkin tak akan pernah ada. ${ }^{23}$

Menurut J.M. Bochenski dalam Jujun S. Suriasumantri berfikir adalah perkembangan ide dan konsep, definisi ini nampak sangat sederhana namun substansinya cukup mendalam, berfikir bukanlah kegiatan fisik namun merupakan kegiatan mental, bila seseorang secara mental sedang mengikatkan diri dengan sesuatu dan sesuatu itu terus berjalan dalam ingatannya, maka orang tersebut bisa dikatakan sedang berfikir. Jika demikian berarti bahwa berfikir merupakan upaya untuk mencapai pengetahuan. ${ }^{24}$

\section{Logika dan Ilmu Pengetahuan}

Peran Logika

Hadiatmaja dan Kuswa Endah dalam Mukhtar menyatakan bahwa logika merupakan cabang dari filsafat ilmu yang membicarakan masalh berpikir yaitu mengikuti kaidah berpikir logis. Pembahasan dalam ilmu logika yaitu ukuran dan norma berpikir yaitu kemampuan akal budi manusia untuk mencapai kebenaran, membicarakan aturan berpikir agar dapat mengambil kesimpulan yang benar dan tepat. ${ }^{25}$

Logika mempelajari masalah penalaran (reasoning) dan tidak semua kegiatan berpikir itu adalah sebuah penalaran. Kegiatan penalaran dalam logika disebut juga dengan penalaran logis. Penalaran adalah proses dari akal manusia yang berusaha untuk menimbulkan suatu keterangan baru dari beberapa keterangan yang sebelumnya sudah ada. Dalam logika, keterangan yang mendahului disebut premis, sedangkan keterangan yang diturunkannya disebut kesimpulan. Penalaran dianggap sebagai konsep kunci yang menjadi pembahasan dalam logika. Penalaran adalah suatu corak

${ }^{22}$ Op. Cit. Mukhtar, 259.

23 Uhar Suharsaputra, Pengatar Filsafat Ilmu Jilid I .Uiversitas Kuningan, 2004 , 3-8. 1984, 52.

${ }^{24}$ Jujun S. Suriasumantri, Ilmu dalam Perspektif. Jakarta: Gramedia:

${ }^{25}$ Ibid., 262.

TAJDID Vol. XIV, No. 2, Juli-Desember 2015403 
pemikiran khas yang dimiliki manusia untuk memecahkan suatu masalah.

Sehingga Suwardi Endaswara (2012) dala Muhtar terang menyatakan bahwa logika sebagai esensi dari filsafat ilmu. ${ }^{26}$ Oleh demikian dalam filsafat ilmu tidak terlepas dari logika sebagai landasan pokok pengetahuan. Sebab filsafat tanpa logika akan menemukan kegagalan dalam memaknai fenomenologi alam. Logika sememangnya esensi berfikir filsafat ilmu. Sebab filsafat tanpa logika akan kelam. Logika akan membangun kepercayaan seseorang dalam kehidupannya, dimana seseorang akan mampu untuk mengembangkan potensi dirinya jika menggunakan logika berfikir yang baik dan benar.

Kegiatan berpikir atau akal budi manusia. Dengan berpikir dimaksudkan kegiatan akal untuk mengolah pengetahuan yang telah kita terima melalui panca indra, dan ditujukan untuk mencapai suatu kebenaran. Jadi, dengan istilah berpikir ditunjukkan suatu bentuk kegiatan akal yang khas dan terarah. melamun tidaklah sama dengan berpikir, demikian pula merasakan, pekerjaan panca indera (melihat, mendengar dan sebagainya) dan kegiatan ingatan dan khayalan, meskipun ini semua penting sekali untuk dapat berpikir (dan menghasilkan buah pikiran yang berarti). Tetapi berpikir juga berarti kegiatan kenyataan yang menggerakkan pikiran. kenyataan yang memegang inisiatif.

Dengan kata-kata yang lebih sederhana dapat dikatakan bahwa berpikir adalah berbicara dengan dirinya sendiri di dalam batin yaitu mulai dari mempertimbangkan, merenungkan, menganalisa, membuktikan sesuatu, menunjukkan alasan-alasan, menarik kesimpulan, meneliti suatu jalan pikiran dan sebagainya.

Manfaat Logika dalam Pengembangan Ilmu Pengetahuan

Sudah tidak dinafikan lagi bahwasanya logika sudah jelas memberi manfaat bagi kehidupan manusia. Setiap orang sejak masa lampau sudah memikirkan dunia ini dengan logika. Aristoteles dan para pengikutnya memandang logika tidak dikategorikan sebagai suatu ilmu diantara ilmu-ilmu lain. Menurut Aristoteles logika adalah persiapan yang mendahului ilmu. Pembicaraan dan manfaat logika terus diperbincangkan dan terus

${ }^{26}$ Muhtar. 261.

404 TAJDID Vol. XIV, No. 2, Juli-Desember 2015 
memberikan manfaat selagi manusia masih menggunakan akal pikirannya. $^{27}$

Menurut Andi Hakim dalam Jujun Suriasumantri mengemukakan bahwa sekiranya hewan mempunyai kemampuan menalar, maka bukan harimau Jawa yang sekarang ini yang dilestarikan jangan punah, melainkan manusia jawa. Kemampuan menalar ini menyebabkan manusia mampu mengembangkan pengetahuan yang merupakan rahasia kekuasaan-kekuasaannya. ${ }^{28}$

Secara simbolik manusia memakan buah pengetahuan lewat Adam dan Hawa dan setelah itu manusia harus hidup berbekal pengetahuan. Dia mengetahui mana yang benar dan mana yang salah, mana yang baik dan mana yang buruk, serta mana yang indah dan mana yang jelek. Manusia adalah satu-satunya mahluk yang mengembangkan pengetahuan ini secara sungguh-sungguh. Hewan juga mempunyai pengetahuan namun pengetahuan ini terbatas untuk kelangsungan hidupnya.

Berpikir merupakan suatu kegiatan untuk menemukan pengetahuan yang benar. Apa yang disebut benar bagi tiap orang adalah tidak sama, maka oleh sebab itu kegiatan proses berpikir untuk menghasilkan pengetahuan yang benar itu-pun berbeda-beda. Menurut Jujun Suriasumantri penalaran merupakan suatu proses perpikir dalam menarik suatu kesimpulan yang berupa pengetahuan. Manusia pada hakikatnya merupakan mahluk yang berpikir, merasa, bersikap, dan bertindak. ${ }^{29}$

Pengetahuan yang dihasilkan penalaran itu mempunyai dasar kebenaran, maka proses berpikir itu harus dilakukan suatu cara tertentu. Suatu penarikan kesimpulan baru dianggap sahih (valid) kalau proses kesimpulan terseburt dilakukan menurut cara tertentu. Cara penarikan kesimpulan ini disebut logika, dimana logika secara luas dapat didefinisikan sebagai pengkajian untuk berpikir secara sahih. Terdapat bermacam-macam cara penarikan

${ }^{27}$ Jujun S. Suriasumantri, hal 264.

28 Jujun S. Suriassumantri, Filsafat Ilmu: Sebuah Pengantar Populer. Jakarta : Pustaka Sinar Harapan. 2009, 173-181.

${ }^{29}$ Ibid. 
kesimpulan, namun untuk kesesuaian studi yang memusatkan diri pada penalaran ilmiah. ${ }^{30}$

Baik logika deduktif maupun logika induktif dalam proses penalarannya, merupakan premis-premis yang berupa pengetahuan yang dianggapnya benar. Kenyataan ini membawa kita kepada sebuah pernyataan yaitu bagaimanakah caranya mendapatkan pengetahuan yang benar. Sebenarnya terdapat dua cara yang pokok bagi manusia untuk mendapatkan pengetahuan yang benar. Yang pertama mendasarkan diri pada rasio dan yang kedua mendasarkan diri kepada pengalaman.

Disamping rasionalisme dan empirisme masih terdapat cara untuk mendapatkan pengetahuan yang lain. Yang penting untuk kita ketahuai adalah intuisi dan wahyu. Namun sampai sekarang ini pengetahuan yang didapatkan secara rasional dan empiris. Intuisi merupakan pengetahuan yang didapatkan tanpa melalui proses penalaran tertentu. Intuisi bersipat personal dan tidak bisa diramalkan. Pengetahuan Intuitif dapat dipergunakan sebagai hipotesis bagi analisis selanjutnya dalam menentukan benar tidaknya pernyataan yang dikemukakannya. Maslow dalam Stanley mengemukakan intuisi ini merupakan pengalaman puncak. Sedangkan bagi sendiri Nietzsche dalam George mengemukakan intuisi merupakan inteligensi yang paling tinggi. ${ }^{31}$

Penalaran mempunyai banyak masalah yang sulit. Namun yang terpenting adalah bagaimana cara kita menemukan atau mengetahui suatu objek yang belum tentu lewat penarikan kesimpulan. Saya mengetahui masalah ini tampaknya sangat sulit bagi saya dan saya tak bisa memberikan pemecahan yang lengkap. Namun suatu hal yang pasti bahwa kita dapat mempelajari sesuatu dengan diskusi.

Pengetahuan merupakan segala sesuatu yg diketahui manusia, hal tersebut adalah bahagian besar dari logika dalam perkembangan pengetahuan manusia. Suatu hal yang menjadi pengetahuan selalu terdiri atas unsur yang mengetahui dan yang diketahui serta kesadaran mengenai hal yang ingin diketahui. Karena itu pengetahuan menuntut adanya subjek yang mempunyai kesadaran
${ }^{30}$ Ibid.
${ }^{31}$ Ibid. 
untuk mengetahui tentang sesuatu dan objek yang merupakan sesuatu yang dihadapinya sebagai hal yang ingin diketahuinya.

Burhanuddin Salam mengklasifikasikan bahwa pengetahuan yang diperoleh manusia dapat dikelompokkan menjadi empat kelompok, yaitu pengetahuan biasa (common sense) yaitu pengetahuan biasa, atau dapat kita pahami bahwa pengetahuan ini adalah pengetahuan yang karena seseorang memiliki sesuatau karena menerima secara baik. Orang menyebut sesuatu itu merah karen memang merah, orang menyebut benda itu panas karena memang benda itu panas dan seterusnya. Pengetahuan Ilmu (science) yaitu ilmu pengetahuan yang bersifat kuantitatif dan objektif, seperti ilmu alam dan sebagainya.

Pengetahuan Filsafat, yakni ilmu pengetahuan yang diperoleh dari pemikiran yang bersifat kontemplatif dan spekulatif. Pengetahuan filsafat lebih menekankan pada universalitas dan kedalaman kajian tentang sesuatu. Pengetahuan Agama, yaitu pengetahuan yang hanya didapat dari Tuhan lewat para utusanNya. Pengetahuan agama bersifat mutlak dan wajib diyakini oleh para pemeluk agama. Jadi perbedaan antara pengetahuan dan ilmu adalah jika pengetahuan (knowledge) adalah hasil tahu manusia untuk memahami suatu objek tertentu, sedangkan ilmu (science) adalah pengetahuan yang bersifat positif dan sistematis.

Berfikir mensyaratkan adanya pengetahuan (Knowledge) atau sesuatu yang diketahui agar pencapaian pengetahuan baru lainnya dapat berproses dengan benar, sekarang apa yang dimaksud dengan pengetahuan ?, menurut Langeveld pengetahuan ialah kesatuan subjek yang mengetahui dan objek yang diketahui, di tempat lain dia mengemukakan bahwa pengetahuan merupakan kesatuan subjek yang mengetahui dengan objek yang diketahui, suatu kesatuan dalam mana objek itu dipandang oleh subjek sebagai dikenalinya.

Dengan demikian pengetahuan selalu berkaitan dengan objek yang diketahui, sedangkan Feibleman menyebutnya hubungan subjek dan objek (Knowledge : relation between object and subject). Subjek adalah individu yang punya kemampuan mengetahui (berakal) dan objek adalah benda-benda atau hal-hal yang ingin diketahui. Individu (manusia) merupakan suatu realitas 
dan benda-benda merupakan realitas yang lain, hubungan keduanya merupakan proses untuk mengetahui dan bila bersatu jadilah pengetahuan bagi manusia.

Di sini terlihat bahwa subjek mesti berpartisipasi aktif dalam proses penyatuan sedang objek pun harus berpartisipasi dalam keadaannya, subjek merupakan suatu realitas demikian juga objek, ke dua realitas ini berproses dalam suatu interaksi partisipatif, tanpa semua ini mustahil pengetahuan terjadi, hal ini sejalan dengan pendapat Max Scheler yang menyatakan bahwa pengetahuan sebagai partisipasi oleh suatu realita dalam suatu realita yang lain, tetapi tanpa modifikasi-modifikasi dalam kualitas yang lain itu. Sebaliknya subjek yang mengetahui itu dipengaruhi oleh objek yang diketahuinya.

Pengetahuan pada hakikatnya merupakan segenap apa yang diketahui tentang objek tertentu, termasuk ke dalamnya ilmu (Jujun $S$ Suriasumantri,), Pengetahuan tentang objek selalu melibatkan dua unsur yakni unsur representasi tetap dan tak terlukiskan serta unsur penapsiran konsep yang menunjukan respon pemikiran.

Unsur konsep disebut unsur formal sedang unsur tetap adalah unsur material atau isi (Maurice Mandelbaum). Interaksi antara objek dengan subjek yang menafsirkan, menjadikan pemahaman subjek (manusia) atas objek menjadi jelas, terarah dan sistimatis sehingga dapat membantu memecahkan berbagai masalah yang dihadapi. Pengetahuan tumbuh sejalan dengan bertambahnya pengalaman, untuk itu diperlukan informasi yang bermakna guna menggali pemikiran untuk menghadapi realitas dunia dimana seorang itu hidup (Harold H Titus).

Gerak sirkuler antara berfikir dan pengetahuan akan terus membesar mengingat pengetahuan pada dasarnya bersifat akumulatit, semakin banyak pengetahuan yang dimiliki seseorang semakin rumit aktivitas berfikir, demikian juga semakin rumit aktivitas berfikir semakin kaya akumulasi pengetahuan.

Semakin akumulatif pengetahuan manusia semakin rumit, namun semakin memungkinkan untuk melihat pola umum serta mensistimatisirnya dalam suatu kerangka tertentu, sehingga lahirlah pengetahuan ilmiah (ilmu), disamping itu terdapat pula orang-orang yang tidak hanya puas dengan mengetahui, mereka ini 
mencoba memikirkan hakekat dan kebenaran yang diketahuinya secara radikal dan mendalam, maka lahirlah pengetahuan filsafat, oleh karena itu berfikir dan pengetahuan dilihat dari ciri prosesnya dapat dibagi ke dalam Berfikir biasa dan sederhana menghasilkan pengetahuan biasa (pengetahuan eksistensial). Berfikir sistematis faktual tentang objek tertentu menghasilkan pengetahuan ilmiah (ilmu). Berfikir radikal tentang hakekat sesuatu menghasilkan pengetahuan filosofis (filsafat)

Semua jenis berfikir dan pengetahuan tersebut di atas mempunyai poisisi dan manfaatnya masing-masing, perbedaan hanyalah bersifat gradual, sebab semuanya tetap merupakan sifat yang inheren dengan manusia. Sifat inheren berfikir dan berpengetahuan pada manusia telah menjadi pendorong bagi upaya-upaya untuk lebih memahami kaidah-kaidah berfikir benar (logika), dan semua ini makin memerlukan keakhlian, sehingga makin rumit tingkatan berfikir dan pengetahuan makin sedikit yang mempunyai kemampuan tersebut, namun serendah apapun gradasi berpikir dan berpengetahuan yang dimiliki seseorang tetap saja mereka bisa menggunakan akalnya untuk berfikir untuk memperoleh pengetahuan, terutama dalam menghadapi masalahmasalah kehidupan, sehingga manusia dapat mempertahankan hidupnya (pengetahuan macam ini disebut pengetahuan eksistensial).

Berpengetahuan merupakan syarat mutlak bagi manusia untuk mempertahankan hidupnya, dan untuk itu dalam diri manusia telah terdapat akal yang dapat dipergunakan berfikir untuk lebih mendalami dan memperluas pengetahuan. Paling tidak terdapat dua alasan mengapa manusia memerlukan pengetahuan/ilmu yaitu manusia tidak bisa hidup dalam alam yang belum terolah, sementara binatang siap hidup di alam asli dengan berbagai kemampuan bawaannya dan manusia merupakan makhluk yang selalu bertanya baik implisit maupun eksplisit dan kemampuan berfikir serta pengetahuan merupakan sarana untuk menjawabnya.

Dengan demikian dapat dikatakan manfaat logika adalah pertama, melatih jiwa manusia agar dapat memperhalus jalan pemikirannya. Kedua, mendidik kekuatan akan fikiran dan mengembangkanya degan sebaik-baiknya, dengan melatih dan 
membiasakan mengadakan penyelidikan akan tentang cara berfikir itu sendiri. Maka dengan membiasakan latihan berfikir, manusia akan mudah dan cepat mengetahui dimana letak kesalahannya sehingga mampu berfikir cermat tepat dan lurus.

Logika Deduktif dan Induktif dalam Ilmu Pengetahuan

Berfikir adalah merupakan suatu proses, proses berfikir ini disebut bernalar. Dalam bernalar biasanya manusia malakukannya dengan menggunakan berbagai macam asumsi dalam menarik kesimpulan. Dalam menarik kesimpulan maka biasanya dengan menggunakan logika berfikir dan menggunakan dua macam pendekatan atau metode yakni: metode deduktif adan induktif. Inilah merupakan keistimewaan manusia terhadap makhluk lainnya.

Setiap makluk hidup di dunia ini, manusia dan hewan, memiliki otak. Karena memiliki otak maka manusia dan hewan mampu berpikir. Karena mampu berpikir maka manusia dan hewan mampu menghasilkan pengetahuan, dimana pengetahuan ini digunakan untuk memperbaiki kualitas hidupnya. Pada dasarnya hewan juga memiliki pengetahuan, namun pengetahuannya dihasilkan melalui proses berpikir tanpa penalaran, sehingga manfaat pengetahuannya sangat terbatas yaitu hanya untuk kelangsungan hidupnya.

Manusia sering disebut makhluk Homo Faber yaitu makluk yang membuat alat karena berkembangnya ilmu pengetahuan tersebut memerlukan alat. Sampai sekarang manusia menuju era peradaban yang sudah lebih maju karena proses berpikir dan menggunakan sarana berpikir ilmiah. ${ }^{32}$

Kemampuan menalar yang di miliki manusia menyebabkan manusia mampu mengembangkan pengetahuan jauh lebih maju dari pada hewan. Bahkan manusia adalah satu-satunya makluk yang mengembangkan pengetahuannya secara sungguh-sungguh di bumi ini. Manusia mengetahui mana yang benar dan mana yang salah, mana yang baik dan mana yang buruk, serta mana yang indah dan mana yang jelek. Penalaran merupakan suatu proses

32 Jujun S. Suriassumantri, Filsafat Ilmu: Sebuah Pengantar Populer. Jakarta : $\quad$ Pustaka Sinar Harapan. 2009, hal. 165. 
berpikir dalam menarik suatu kesimpulan yang berupa pengetahuan.

Penalaran menghasilkan pengetahuan yang dikaitkan dengan kegiatan berpikir dan bukan dengan perasaan. Meskipun demikian patut kita sadari bahwa tidak semua kegiatan berpikir menyandarkan diri pada penalaran. Jadi penalaran merupakan kegiatan berpikir yang mempunyai karakteristik tertentu dalam menemukan kebenaran.

Terdapat berbagai cara untuk melakukan penalaran, diantaranya adalah deduktif, induktif dan abduktif. Penalaran deduktif menarik kesimpulan secara logika dari premis yang diberikan. Perlu diketahui bahwa penalaran deduktif adalah mengambil kesimpulan secara logika dari premis yang tersedia. Hasilnya tidak selalu dengan fakta kebenaran yang kita ketahui. Induktif adalah mengeneralisasi atau membuat umum suatu hal dari kasus-kasus yang pernah kita lihat atau alami untuk menarik kesimpulan mengenai hal lain yang belum pernah kita lihat atau alami.

Abduktif merupakan penalaran dari sebuah fakta ke aksi atau kondisi yang mengakibatkan fakta tersebut terjadi. Metode ini digunakan untuk menjelaskan kejadian yang kita amati. Penalaran merupakan proses berpikir untuk mendapatkan pengetahuan. Supaya pengetahuan yang didapat benar maka penarikan kesimpulan harus dilakukan dengan benar atau mengikuti pola tertentu. Cara penarikan kesimpulan disebut logika. Ada dua cara penarikan kesimpulan yaitu logika induktif dan logika deduktif.

Induksi merupakan cara berpikir dengan melakukan penarikan kesimpulan yang bersifat umum/general berdasarkan kasus-kasus individu atau spesifik. Kentungan kesimpulan yang bersifat umum ini yang pertama adalah ekonomis. Dan yang ke 2 bahwa kesimpulan umum ini memungkinkan proses penalaran berikutnya baik induktif maupun deduktif. Dengan demikian memungkinkan untuk mendapatkan pengetahuan secara sistematis.

Deduksi merupakan cara berpikir untuk melakukan penarikan kesimpulan dari peryataan umum menjadi pernyataan khusus. Penalaran deduktif menggunakan pola berpikir silogisme. Dari premis mayor dan premis minor kemudian ditarik suatu 
kesimpulan. Contoh : Semua makhluk membutuhkan makan premis mayor. Budi adalah makhluk-premis minor. Jadi Budi memiliki mata-kesimpulan.

Ketepatan penarikan kesimpulan bergantung pada kebenaran premis mayor, kebenaran premis minor dan cara/keabsahan penarikan kesimpulan. Baik logika deduktif maupun induktif menggunakan pengetahuan sebagai premis-premisnya berupa pengatahuan yang dianggapnya benar. Kaum rasionalis menggunakan metode deduktif untuk menyusun pengetahuannya. Premis yang digunakannya berasal dari ide yang menurut anggapannya jelas dan dapat diterima.

Begitu juga dalam penelitian ilmiah terdapat dua cara penarikan kesimpulan melalui cara kerja logika yaitu adalah induktif dan deduktif. Logika induktif adalah cara penarikan kesimpulan dari kasus-kasus individual nyata menjadi kesimpulan yang bersifat umum dan rasional. Logika deduktif adalah cara penarikan kesimpulan dari hal-hal yang bersifat umum rasional menjadi kasus-kasus yang bersifat khusus sesuai fakta di lapangan. ${ }^{33}$

Dari sini kemudian muncul paham idealisme. Yaitu paham yang mengakui bahwa sudah ada prinsip yang ada jauh sebelum manusia memikirkannya. Prinsip yang sudah ada ini dapat diketahui manusia memlalui kemampuan berpikir rasionalnya. Para pemikir rasional ini cenderung subjektif, jika tidak ada konsensus yang disepakati. Karena ide tau prinsip bagi si A belum tentu sama dengan si B.

Berlawanan dengan kaum rasionalis, kaum empiris mendapatkan pengetahuan melaui pengalaman yang bersifat konkret yang diperoleh lewat tangkapan pancaindera manusia. Gejala-gejal yang diamati kemudian ditelaah lebih lanjut dan mendapatkan pola tertentu setelah mendapat karakteristik persamaan dan pengulanngan dari pengamatan. Kaum empiris menganggap bahwa dunia fisik adalah nyata karena merupakan gejala yang tertangkap panca indera.

Lebih jelasnya bahwa penalaran deduktif juga merupakan cara berfikir yang bertolak dari pernyataan yang bersifat umum

33 Cecep Sumarna, Filsafat Ilmu. Bandung: Mulia Press, 2008, 150. 
untuk menarik kesimpulan yang bersifat khusus, dengan demikian kegiatan berfikir yang berlawanan dengan induksi. Penarikan kesimpulan secara deduktif ini menggunakan pola berpikir yang disebut silogisme. Silogisme terdiri atas dua pernyataan dan sebuah kesimpulan. Kedua pernyataan itu disebut premis mayor dan premis minor.

Penalaran deduktif merupakan salah satu cara berpikir logis dan analitis, berkat pengamatan yang semakin sestimatis dan kritis, serta makin bertambahnya pengetahuan yang diperoleh, lambat laun manusia berusaha menjawab masalah dengan cara rasional dengan meninggalkan cara irasional atau mitos. Pemecahan secara rasional berarti menggunakan rasio (daya pikir) dalam usaha memperoleh pengetahuan yang benar. Faham yang mendasarkan rasio untuk memperoleh kebenaran itu disebut faham rasionalisme. Dalam menyusun pengetahuan kaum rasionalis sering menggunakan penalaran deduktif.

\section{Penutup}

logika adalah suatu cabang filsafat yang membahas tentang aturan-aturan, asas-sasa, hukum-hukum dan metode atau prosedur dalam mencapai pengetahuan secara rasional dan benar. merupakan suatu cara untuk mendapatkan suatu pengetahuan dengan menggunakan akal pikiran, kata dan bahasa yang dilakukan secara sistematis. Logika dapat disistematisasikan menjadi beberapa golongan hal tersebut tergantung dari perspektif mana kita melihatnya dilihat dari kualitasnya logika dapat dibedakan menjadi dua yakni logika naturalis ( logika alamiah) dan logika artifisialis (logika ilmiah). Logika artifisialis pertama-tama disusun oleh Aristoteles (384-322 SM), sebagai sebuah ilmu tentang hukumhukum berpikir guna memelihara jalan pikiran dari setiap kekeliruan. Logika sebagai ilmu baru pada waktu itu, disebut dengan nama "analitika" dan "dialektika".

Penalaran merupakan suatu proses berpikir dalam menarik sesuatu kesimpulan yang berupa pengetahuan. Manusia pada hakikatnya merupakan makhluk yang berpikir, merasa, bersikap, dan bertindak. Sikap dan tindakannya yang bersumber pada pengetahuan yang didapatkan melalui kegiatan merasa atau berpikir. Penalaran menghasilkan pengetahuan yang dikaitkan 
dengan kegiatan berpikir. Penalaran merupakan suatu proses berpikir dalam menarik sesuatu kesimpulan yang berupa pengetahuan. Jadi penalaran merupakan salah satu atau proses dalam berpikir yang menggabungkan dua pemikiran atau lebih untuk menarik sebuah kesimpulan untuk mendapatkan pengetahuan baru.

\section{Daftar Pustaka}

Departemen Agama RI. Al-Qur'an dan Terjemahannya. Surabaya: Surya Cipta Aksara. 1995

Afid Burhanuddin, Filsafat Ilmu: Sarana Berpikir Ilmiah. Paper: STKIP PGRI Pacitan, 2014.

Amsal Bakhtiar, Filsafat Ilmu. Jakarta: Raja Grafindo Persada, 2004.

Cecep Sumarna, Filsafat Ilmu. Bandung: Mulia Press, 2008.

Fuad Ihsan, Filsafat Ilmu, (Jakarta: Rineka Cipta.2010

Harun Nasution. Islam Rasional. Bandung: Mizan. 1996.

Hasbullah Bakri, Sistematik Filsafat, Jakarta: Widjaya. 1986.

Iu Rusliana. Filsafat Ilmu. Bandung: Refika Aditama.2015.

Jujun S. Suriassumantri. Filsafat Ilmu: Sebuah Pengantar

Populer. Jakarta: Pustaka Sinar Harapan. 2009.

Jujun S. Suriasumantri, Ilmu dalam Perspektif. Jakarta: Gramedia: 1984.

Mukhtar Latif, Orientasi ke Arah Filsafat Ilmu. Jakarta: Kencana Prenadamedia Group, 2014.

Mundiri, Logika, Jakarta: PT.Raja Grafindo Persada, 2008

Suparlan Suhartono, Sejarah Pemikiran Filsafat Modern. Yogyakarta: Ar Ruzz Media, 2005.

Surajiyo, Filsafat Ilmu dan Perkembangannya di Indonesia. Jakarta: Bumi Aksara, 2013.

Susanto, Filsafat Ilmu Suatu Kajian dalam Dimensi Ontologis, Epistemologis dan Aksiologis. Jakarta: Bumi Aksara, 2013.

Uhar Suharsaputra, Pengatar Filsafat Ilmu Jilid I, Uiversitas Kuningan, 2004. 